\title{
The Development and Sinicization of Marx's Moral Concept of Ethics
}

\author{
Peng Chen ${ }^{1}$,Wen-yu Xin ${ }^{2}$ \\ ${ }^{1}$ Ministry of Social Science Teaching, HebeiFinanceUniversity, Baoding,China \\ ${ }^{2}$ Scientific Research Office, HebeiFinanceUniversity, Baoding,China
}

\begin{abstract}
The ethics of Marx himself and Marx's concept of development of the moral concept of development is not lump together, in fact, in the related articles of the Marx doctrine, he is always in the spirit of criticizing the consequence of capitalism from aspects like the social system, economic system, and ethics and so on. Arouse the proletarian struggle for their own rights, and even this sharp view of "communism is not advocating the practice of morality". So there is little discussion about morality, and Marx himself for the moral view had passed some stages of development, in this paper, we focus on the study of Marx's developing morality and signalization of that.
\end{abstract}

Keywords:Marx; moral values; Chinese style

\section{INTRODUCTION}

Marx is a theists in the initial, middle school he was influenced by family, school and society comprehensive, accept the Christian theological ethics. Therefore, Marx was a theist when he was a teenager, he studied and accepted the knowledge conducted by the Christian schools, and he thought the origin of the world is divine guidance. In middle school graduation thesis "on the composition of religion" in his from the notion of Christ and believers is deduced love Christian moral commandments of god and love the neighbor, and think that "all moral behavior is for the love of Christ, for the love of god, is the root of this purity, moral is free from all worldly things and become a true divine things". ${ }^{11}$ Thus, Marx was be influenced by Christian deeply in his Youth, he also could not escape the Christian doctrine of content for the ethics moral values, form their own views and opinions. However, as a theist influenced by Christian when he was a teenager, his family and school environment also taught him theism in their education constantly, in the presence of God, Marx was always on the "people" of great concern, he firmly maintains the initiative of person, placed people's initiative on a high position. When he describing the relationship between man and god, with the intention of "Under master ${ }^{[2]}$, which illustrates he put "man "in an important position despite his theistic. He believed that in the presence of God, people should not be afraid of, but should be a master, just because of some special reasons and in the presence of God to be insulted. This is why many materialism of Marx after works always in the person's value in the important position. And this can explain the important position of man in many of his materialist works.

University period Marx began to ponder on the issue of theism, under the influence and youth Hegel's own study, Marx gradually realized the limitations of self-recognition, he began to understand the outside in a wider world, he was exposed to the various schools of philosophy in university life, he also began to understand and think real source in the world, is the matter? Or consciousness or spirit. With the deepening of his learning, he gradually be out of the idealism of the cage, to research on the materialism, road. In German ideology in Marx's system expounded his view of history, and puts forward the moral and religious, philosophical and political, belongs to the social ideology, is a reflection of social material production, is the result of social division of labor, he pointed out that "individual how to show their life, this is in agreement with their production, and how they are made. So what is personal, it depends on 
their production of the material conditions of ${ }^{[3]}$ at this point, Marx's historical materialism under the principles of morality basic formation, Marx always thinks that moral ethics and the social ideological field content are determined by individual social reality, has an inseparable relation with the specific social reality, as a kind of social ideology, ethics morals view for the development of social existence has certain effect. In the slave society, people thought that the slaves could be slaved by an appendage of the Lord, traded, and even easily killed. Those action are not against the moral standard of conduct. The slaves had no human rights and lived a very miserable life. But with the continuous development of productive forces, some of the slaves began to realize the independent consciousness, they began destroying labor instruments to slave revolt oppression, their sense of self awakening, in fact, it is a change of social consciousness with the productivity development, more and more slaves to realize this idea, and in the beginning of unity rise up and overthrow the slave owning aristocracy domination, social ideology on the reaction of social existence began to emerge. But with the continuous development of productive forces, in capital society, on the one hand, slavery had been abolished not to exist. The social legal and ethical consciousness gradually come into perfectness, and the sale of population is not only not allowed in moral, but also subject to legal sanctions. This is actually a social ideology development and improvement based the social ethics. After he has been sticking to this principle also discusses many specific problems of capitalism, he will be in a capitalist society problems due to the fundamental social existence, and thus demonstrates the capitalist ethics must be as the change of the mode of production and change. And proves that moral content of capitalism inevitably change along with the change of the mode of production in a certain. Since the Marx doctrine was introduced into China, struggling nearly 100 years, we have established the guiding position of Marx's Theory. But China is a country with a history of several thousand years of feudal culture has. For a long time the feudal ethics morals view has a deep influence on the masses of the people, studying and inheriting the Marx doctrine ethics is an important part of China's current construction of spiritual civilization, we cannot be ignored it. We have in view of morality still inherited Marx's point of view until now. Until now when we think of moral is still inherited Marx's point of view, adhere to the concept of historical materialism to view our continuous development of society and morality.

\section{In the process of the signalization of Marxist ethics development}

\subsection{Moral concept of the early Pioneers of Marxism}

Before Marxism was introduced into our country, in the traditional feudal ethics laws as the core of the feudal moral occupies the dominant position.It is very difficult to change the ethics of the social ideology rooted in the human brain, after the opium war, China's enlightened men from all walks of life to find the development direction of China made great contributions, But they had not realized that the decadent feudal system and the imperial powers behind the pressure is an important reason why modern China cannot walk out from the shadow, they made a lot of efforts in learning objects and imitate system, but had not found the essence of mining to the development of things, also lead to these people with lofty ideals have not always been able to find the real way out of China. Moral culture is changed a little but never can be more clearly revealed.Since the 20th century Marxism was introduced into China, its ethics thought is arguably had two huge transformation, the first transition is from the semi-colonial and semi-feudal moral through social revolution into the process of socialist morality and communist morality. Happened to the new culture movement in the late October revolution and the May 4th movement, Marxism was introduced into China, China's advanced intellectuals began to Marxist world outlook and methodology to observe China's future and destiny, which makes this part of the intellectuals from democracy to the path of communism. Proposed by early communist Li Dazhao, Chen Duxiu "by today, decay and static, both Oriental civilization and western civilization and scramble to material, to save the crisis of the world, not 
has the rise of the third kind of civilization, is not enough to cross the line." ${ }^{[4]}$ This shows that they have realized that beginning from the point of view of social ideology, pursuing China development way in a civilized force. The traditional feudal civilization has begun to gradually decline, the Western civilization in the war of aggression around the world extort excessive taxes and levies, brought grave disaster to the world and backward country, we should not follow it. Therefore, we must dig and find out a new form of civilization, it adapts to the trend of the social development, also is different with the western material civilization, he should be able to offer a glimmer of hope for the sons and daughters of the Chinese nation in the disaster. So they began to consider the development of the society from the perspective of ideological civilization many problems, and found the important guiding ideology of Marxism. At this point, these early communists began on the guided by the Marxism of China's development path, the Marxist ethics also begin to form. "Achieved by the backward moral advanced moral, by the scientific ethics thought to science ethics thought success". ${ }^{[5]}$ In the traditional feudal society, many ethical concepts were out of times, such as the three cardinal guides, which thought that women were inferior to men. These traditional ideas all belong to the nonscientific ethics thoughts, we should abandon it. After the advanced Marx nationalists was introduced into China scientific theory, China is able to change the semi colonial and semi feudal social historical appearance. By the change of social system as a start, Calling on the people to learn and understand the advanced ideological with this firm, inspiring spirit power, social development is always forward, people's ethics and morality also changed with the development of society produced tremendous change.People's living habits and moral pursuits change with certain social existence. The fact proves that our country has experienced many times of success or failure of the reform and revolution. The Marx doctrine - the pioneers of the choice is correct. The broad masses of the people have gradually abandoned the traditional feudal system, begun to accept the new social custom. After the shift of Mao Zedong, Deng Xiaoping based on the basic idea of Marxism, combining the situation of revolution and construction is put forward in accordance with actual development of the moral view provides important theoretical and practical basis

\subsection{Ethics view of Mao Zedong}

As a strong successor of Marxist theory, Mao Zedong is one of the founders of the communist party of China, he is this statement for the essence of moral values: "morality is we humans on economic life and other requirements of the specific reaction, different classes have different moral values, this is our theory of good and evil." ${ }^{[6]}$ Mao Zedong thought in class society moral certainty in class, there is no moral above classes. So we can find that in the revolution led by Mao Zedong, including a period of time at the beginning of the founding, he emphasizes that our country is the socialist countries guided by the proletariat socialist countries, so our moral values should also has the same essence with the proletariat. In the early years of the new nation, our moral values is politicized revolutionary proletarian revolutionary environment ethics requires people to have a noble personality and mental state for a long time, especially the moral character of selfless, not the value pursuit of self-interest, people occupies a very prominent position. Before setting up our nation, in the flames of war over the years, people were rudely crushed by capitalism, imperialism, and bureaucratic capitalism, and lack of material. Mao Zedong led the Communist pioneer team, with the United Front and various struggles, and walked out the revolutionary road "from the masses, to the masses". Our revolutionary fighters firmly struggled in the years, all showed the selfless service to the people, and put one's heart and soul into the noble moral sentiment. On the basis of infected countless people, our army still follow the proletariat in the material, and pursuit in moral extremely in scarce years. Mao Zedong at the core of the ethics is the ethical spirit of serving the people heart and soul and selfless spirit realm, at the beginning of the revolution and the founding of the moral requirements in solidarity, fighting for people's support, and many other aspects play an extremely important role. And for a long period of time, 
people's standard of living may be low, but the mental state of people are very rich, people holding a build socialism heart of enterprising, for the social various aspects of construction contributes an own strength. This shows that Mao Zedong dominated by "political reform \&opening-up" of moral education at the time of the social and historical conditions is necessary and play an important role.

The new China just established, it suffering from the ravages of war, the domestic situation of basic construction cannot be carried out, but our country has emerged a lot of advanced model task in this difficult environment. In the oilfield in Daqing, Wang Jinxi made great contribution to the exploitation of petroleum. Deng Jiaxian, who manufacture the two bombs and one satellite for our homeland is also the model that we should learned. These excellent model character is appeared in the guidelines of highly revolutionary morality, these enthusiastic is the source of the construction of the motherland to them for the new China, is also a product of Mao Zedong such high requirements of moral values.

\subsection{Ethics view of Deng Xiaoping}

History tells us that after completed the socialist transformation, we in the process of socialist construction, there have been some problems in "recognized" the people's commune movement suffered serious setbacks, comrade Mao Zedong's later years has made some mistakes. Priorities for revolution, political priority to stick to the moral requirement in the socialist construction period after the in-adaptability of gradually emerge. People's production and life enthusiasm was greatly weakened, socialist construction has gradually slowed down, so that the initial stage of development of the socialist modernization construction in the basic state of stagnation. Our state leaders began to reflection and self-criticism, what aspects of the problems of current stage problem? After the Third Plenary Session of the eleven, the party was reestablished the ideological line of emancipating the mind, seek truth from facts, made the major move of the party and the national work focus shifted to economic construction, reform and opening up policy has been preluded. After the reform and opening up, people are faced up richer and more colorful opening world than their original living environment. Various factors, previously occluded state in the status is broken. Especially after opening the socialist market economy, more and more people create a huge economic benefit for themselves and the society, through their own hard work-legitimate business. With the rapid development of economy, people's ideological and moral level and for some ethical views are gradually changing. We think that the original individual economy - small business is to take the capitalist road, keeping capitalism. All things are the dross and should be abandoned. After the reform and opening up, the idea faded down gradually. Deng Xiaoping stressed that "whether white cat or black cat, which one catching mice is a good cat". The economic system itself is no social attribution, but to see what kind of social system it services. Deng Xiaoping inherited Mao Zedong's ethical thought in the communist moral advanced on the basis of selfless, discusses the socialist principle of material benefits of important value in socialist construction. Points out that in the development of the national macroscopic direction to adhere to the economic construction as the center, to develop the social productivity, argues that in the development of the socialist market economy on the basis of moral construction. Comrade Deng Xiaoping perception of socialist morality, not constrained by the paper of Marxism, but bravely stood in the social development of the macro backdrop, in his view, "poverty is not socialism, the essence of socialism is to eliminate poverty, therefore cannot be blindly do moral justification for the poor". ${ }^{[7]}$ In addition, after the third plenary session, comrade Deng Xiaoping in the implement the adjustment policy, guarantee the stability and unity, pointed out that "to promote the education the comrades selflessness and service the general situation, the arduous struggle, the spirit of integrity, adhere to the communist ideals and communist morality. We want to build a socialist country should not only have a high degree of material civilization, but also a high degree of spiritual civilization" ${ }^{[8]}$ it moral thought of Deng Xiaoping, in fact, are put forward to ensure the interests of the people's material premise has never given up the pursuit of 
advanced proletarian moral, his ideas implemented from Mao Zedong's "political reform \&opening-up" to "economic ties", greatly enrich the all-round construction of the socialist cause of our theory, further promoted the process of signalization of Marxism.

\subsection{Ethics morals development after Jiang Zemin in our country}

After Deng Xiaoping, the report emphasizes the party's 14 "emphasis on construction of spiritual civilization", in view of the social life in our country after reform and opening up the emergence of new goes against the communist moral phenomenon, comrade kiang zemin to the country's socialist morality in the new science, in January 2001 the national publicity department meeting "in the process of developing socialist market economy, but also constantly strengthen the socialist morality construction, managing state affairs by ethics" ${ }^{[9]}$ this is from the height of the strategy of governing the socialist moral construction will be referred to an extremely important position. The reform and open policy has brought China's rapid economic development, but the attendant is the people pursuit of material strongly and their spiritual world is deserted, the party and the country from the point of view of socialist modernization construction height, timely find out important issues that moral deficiency existed in the society, aiming to the serious spiritual world deserted after the greatly enrich of material wealth, they timely put forward the major strategic requirements that "governing the country with morality", put the Marx moral concept into the modernization of our country socialism cause.

With Hu Jintao represented by a new generation of collective leadership in comrade Jiang Zemin pays attention to the moral construction of further practical constantly enrich and develop the ideological moral construction of important content. On the one hand, our country has its profound traditional ethical culture, on the other hand, with the deepening of the signalization of Marxism, we associated with Marx's moral view to study further. Accordingly, the general secretary $\mathrm{Hu}$ Jintao put forward the people-oriented strategic theory of building a socialist harmonious society, advocating the scientific development concept is suggested economic and social development of the country, the fairness and justice as the fundamental characteristics of a harmonious society, the further development of the ethical and moral thoughts of Marxism with Chinese characteristics. Scientific Outlook on Development is not only an important guiding ideology of China's economic and social development, is also an important idea of the guidelines for the construction of spiritual civilization, Scientific Outlook on Development emphasis on people-oriented, so stick to the major role of the majority of workers in the construction of socialist, this requires the broad masses of the people in China to have firm faith in the Marx doctrine, and continuously improve the to improve their moral. Later, comrade $\mathrm{Hu}$ Jintao put forward "eight honors, eight disgraces" as main content of the socialism outlook for honor and dishonor, the concept of honor and disgrace, on the one hand, embodies our traditional culture, Which provide the foundation for judging between right and wrong, good and evil, beauty and ugliness under the condition of socialist market economy; On the other hand, from the Marxist standpoint, it requires us have noble moral sentiment and make a contribution to our socialist construction.

\section{CONCLUSION}

Ethics is a kind of social ideology, through the continuous development of society and the change of social history, which is very strong. Its long exists in the world we live in. As the clear standards between good and evil, it is an important benchmark for the analysis of the relation between people and people. Through social media, the human heart and traditional habits, the ethics adjust individual behaviors. Under each societies have ethics in conformity with its social and historical development of the concept of the Marx doctrine of ethics, adhere to the view, it is a product of the actual situation of construction and development of our country and the Marx doctrine height with the guidelines of our country, the construction of spiritual civilization and the material civilization construction and the development, all has been advanced. 
After the eighteen big victory is held, emphasizing the General Secretary $\mathrm{Xi}$ Jinping, and continue to move forward in the construction of socialist China characteristics on the road, we should always keep to the socialist path Chinese self-confidence, self-confidence and confidence theory system, for the realization of communism unremitting struggle. Scientific ethics concept is an important guarantee to achieve the goal of spiritual.

\section{References}

[1]Jin Kexi. The Formation of Marx's Moral Values [J].Moral and civilization, p.17, 2001.

[2]Wang Zhen. Discussing Young Marx from Theism to Atheism Thoughts Transformation[J]. World Religion. p.49.2010.

[3]Wang Xinhong. Interpretation of Marx's Marxism Moral Values [J]. Journal of Fu Jian Provincial Committee Party School of CPC. p.16.2013.
[4]Li Dazhao. Li Dazhao [M]. Beijing: people's publishing house, p.36.1984.

[5] Wang Zeying. The Sinicization of Marxist Ethics and Ethical Culture Great Change [J] Social science of Hu Nan normal university: p.22. 2006.

[6]Selected Works of Mao Zedong (volume 3) [M]. Beijing: people's publishing house, p. 84.1999.

[7]Selected works of Deng Xiaoping (volume 2) [M]. Beijing: People's Publishing House, p250.1994.

[8]Jiang Zemin. Discussion of the "three represents"[M]. Beijing: People's Publishing House, p.367.1994.

[9]Li Peichao.Logical thinking on Marx ethical thoughts [J]Contemporary World \& Socialism, 2007(4). 